\title{
CORRIGENDUM
}

\section{Shifts in clostridia, bacteroides and immunoglobulin-coating fecal bacteria associated with weight loss in obese adolescents}

I Nadal, A Santacruz, A Marcos, J Warnberg, JM Garagorri, LA Moreno, M Martin-Matillas, C Campoy, A Martí, A Moleres, M Delgado, OL Veiga, M García-Fuentes, CG Redondo and Y Sanz

International Journal of Obesity (2012) 36, 1370; doi:10.1038/ijo.2012.135

Correction to: International Journal of Obesity (2009) 33, 758-767; The authors would like to apologise for this error. doi:10.1038/ijo.2008.260

Since the publication of this paper the author has noticed that the author name M Garagorri has been listed incorrectly, the correct spelling is JM Garagorri. 